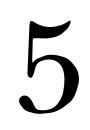

\title{
Dual Style
}

Anybody will tell you: "Flaubert is the author of Madame Bovary." What is then the relation between a man and his works? ... We shall see that it is double: Madame Bovary is defeat and victory; the man who portrays himself in the defeat is not the same as the one who is required in the victory; we must understand what that means.

Jean-Paul Sartre, L'Idiot de la famille

Flaubert's actual practice in a novel such as Madame Bovary may be approached in terms of a notion of dual style or double inscription. On one level, he seems to conform to ordinary social and literary conventions or departs from the expectations they create only in ways that may plausibly be perceived as standard deviations. On other levels, however, conventional norms and expectations are tested and contested in more subversive fashion, at times with a force sufficient to bring about a radical reworking of problems and possibilities. On these other levels, it might be more appropriate to speak of a multiple mode of writing or a plural style, for the effects of the novel are many and varied. One has a complex interaction of critical and more uncanny-or generalized carnivalesque-processes, notably in the form of shifting narrative perspectives. Here duality or multiplicity reenierges through modulations of proximity and distance, empathy and irony, in the relation of the narrator to characters and other objects of narration. And the question arises of the connections among effects that reinforce, criticize, and disorient conventions-as well as between these effects and Flaubert's more explicit "authorial" projects of pure art and muted carnivalization.

Madame Bovary is, as I have already intimated, in a somewhat 
distinctive position among Flaubert's "mature" works. For it is on the very threshold of experimental literature. In it the conventional level of social and literary expectation continues to have a very strong hold and to be operative in a form that cannot be reduced to the level of mere appearance. Its realism is more than trompe-l'oeil, and its world is very close to the recognizable social world of its own time (and, in certain ways, of our own time). It directly transplants elements and situations from a documentary repertoire, and it simulates the documentary-or the ways of conventional reality-in other respects. It may stylize realistic elements in given directions, but the judgment of the extent to which it does so carries with it an ineradicable subjective aspect that would be difficult to control through ordinary procedures of verification or falsification. In any case, its world resembles the ordinary social world of provincial nineteenth-century France to an extent that makes both recognition and discomfort possible. And, in larger respects, what it reveals about that world has a resonance in the problems experienced in later "postindustrial" contexts.

Similarly, there are enough elements of the traditional novel present to make a conventional reading plausible. Flaubert himself was quite aware of this problem and most often saw it in terms of the way he would be contaminated by-or the novel fall short of beauty or pure art because of-its bourgeois subject matter. (For example: "This bourgeois subject brutalizes me. I feel the effects of my Homais" [June 2, 1853].) Flaubert was visibly anxious about becoming stupid in the conventional sense because of the matter he narrated, and he feared resembling those novelists who consorted with similar subjects. Yet at least one blatant differentiating factor in Madame Bovary would seem to be the absence of an authoritative center of moral and cognitive judgment to serve as a reliable guide for the reader. The argument of the defense at the trial, however, is enough to show that this figure may be constructed from various bits of circumstantial evidence and projected into the novel. Flaubert's own striving for harmony and for a unity of style that would conceal more disconcerting movements in narration is effective enough to make those movements pass unnoticed on a more "naive" level of reading. And the very impersonal effect of 


\section{Madame Bovary on Trial}

stylistic unity may itself invite personification that presents a narrator or an author as the unifying force bringing off the harmonizing impression of flowing continuity in narration. Thus Flaubert himself seems to invite an "argument from design" in interpreting the novel. Conversely, with the prosecuting attorney, one may find a simple absence of such a narrator in order to condemn the novel's deviation from the norm. How Madame Bovary elicits conventionalizing (or "recuperative") readings and places them in radical jeopardy will be discussed at greater length in the chapters that follow. Both the conventional relation to ordinary literary and social expectations (conformity and deviance) and the more radical questioning of these expectations are essential for the workings of the novel.

In addition, the radical questioning of convention is itself complex in nature. There is a level on which Madame Bovary engages in a form of criticism that can be called ideological or political crime. Its disclosive force places in fundamental question the norms, categories, and oppositions of a social and political world, and it at least indirectly raises the issue of the need for basic transformation. The untenability of the opposition between marriage and adultery or between the sacred and the profane attests to a perception of sociocultural and political crisis that is shocking in its magnitude. Emma's behavior goes beyond conventional deviance in its threatening tendency to reveal the hollow core of the two pillars of bourgeois order: the family and property. The world in which Emma is driven to suicide and Charles is totally excavated while Homais receives the Legion of Honor does stand condemned. The very discrepancy between what norms should viably do and what they fail to do or allow to be done is an ideological and ethical scandal.

But there are also levels of the novel on which more disorienting or "unsayable" effects-especially modulations of narrative perspective or "voice" that can be jarringly vertiginouscomplicate the problem of criticism and render its objects and, even more, viable alternatives to those objects rather difficult to determine. But complication cannot be identified with cancellation or simple avoidance and denial. Indeed it broaches the question of the actual and desirable roles of more uncanny 
effects in society and culture, including any program for major transformation. These large and even unwieldy issues help give Madame Bovary its liminal position in the history of the novel-a position that makes it an object of ever renewed fascination and a source of interminable commentary.

Sartre also sees in Flaubert a dual style or mode of writing which he relates to an entire series of problems. Sartre raises the question of "style" with reference to the interaction between signifying and nonsignifying dimensions of language use in Flaubert. The signifying use of language involves propositional functions, reference, and disclosure of aspects of the world in a manner linked to practice that can change the given. Its manifestation in literature would seem to be a critical realism in which art functions as a "critical mirror" of the times. The nonsignifying is a matter of indirect communication of what cannot be directly said but only shown in the way language is used. The signifying gives us "what" literature says and the nonsignifying, "how" it says it-its "manière de dire." The nonsignifying also bears on the question of the materiality of language, and Sartre further relates it to what Flaubert termed l'indisable (the unsayable). For Sartre, the relation between the signifying and the nonsignifying is further connected with the fact that Flaubert did not refer to himself as a novelist or even as a poet but wanted to attain the rigor of poetry in prose that remained prose. "'I am a writer,' he said. What should one understand by that?"

An initial understanding of the fact that Flaubert referred to himself as a writer might be that the problems engaging him could not be entirely confined to a given genre such as the novel or even to fiction in contradistinction to nonfiction. These problems had to do with the use of language and its relation to the world on a very fundamental level-problems Sartre approaches in terms of the signifying and nonsignifying dimensions of language use. In "A Plea for Intellectuals," Sartre formulates in pointed fashion the reasons why Flaubert might be seen as positioned at the very crossroads of modern

1. L'Idiot de la famille (3 vols.) (Paris: Gallimard, 1971-72), III, 665. Further references are to volume and page number, and translations are my own. 


\section{Madame Bovary on Trial}

literary problems, and his formulation in certain respects remains operative in L'Idiot de la famille:

The word the writer uses has a much denser materiality than, for example, the mathematical symbol that effaces itself before the signified. One might say that it wants simultaneously to point vaguely toward the signified and to impose itself as a presence, drawing attention to its own density. This is why it has been possible for people to say that to name is simultaneously to present the signified and to kill it, to swallow it in the verbal mass. The word of ordinary language is simultaneously too rich (it overflows by far the concept by its traditional age [son ancienneté traditionnelle], by the ensemble of violences and ceremonies which constitutes its "memory," its "living past") and too poor (it is defined in relation to the ensemble of language as a fixed determination of the latter and not as a supple possibility of expressing the new). In the exact sciences, when the new arises, a word to name it is simultaneously invented by some and rapidly adopted by all. . . . [The writer] prefers to utilize a "current" word and to charge it with a new meaning which is superadded to the old: in general, one might say that the writer has vowed to utilize the whole of ordinary language and nothing but it, with all the misinformative characteristics that limit its range. If the writer adopts ordinary language, it is thus not only insofar as language can transmit knowledge. To write is simultaneously to possess language ... . and not to possess it to the extent that language is other than the writer and other than men. . . . Roland Barthes distinguished between écrivants [literal writers] and écrivains [literary writers]. The literal writer uses languages to transmit information. The literary writer is the custodian of ordinary language, but he goes beyond it and his material is language as nonsignifying or as misinformation. $\mathrm{He}$ is an artisan who produces a certain verbal object by working on the materiality of words; he takes significations as means and the nonsignifying as end. ... If writing consists in communicating, the literary object appears as communication beyond language through the nonsignifying silence which is enclosed by words although it is produced by them. ${ }^{2}$

2. "Plaidoyer pour les intellectuels," Situations VIII (Paris: Gallimard, 1972), 433-37. 
It is significant that Sartre in "A Plea for Intellectuals" applies this analysis to "the contemporary writer, the poet who has declared himself to be a prose writer and lives in the post-World War II world." 3 But it informs his analysis of Flaubert and, aside from giving a fuller idea of Sartre's understanding of Flaubert's contemporaneity, it is, in L'Idiot de la famille, specified to apply to the hermit of Croisset. Indeed the near identity in Sartre's analyses of Flaubert and of contemporary structuralists and poststructuralists provides some sense of what is at stake for Sartre as he comes to terms with Flaubert-a confrontation in which an "anxiety of influence" merges with an anxiety of anticipation. For Sartre's interchange with Flaubert tends to coincide with his debate with contemporary theorists to influence the course of future theory and practice.

In the case of Flaubert as in that of more contemporary theorists, Sartre is often so agitated over the possibly harmful effects of subordinating the signifying to the nonsignifying aspects of language that he devotes relatively little attention to more reciprocal modes of interaction between the two. He does at times see Flaubert as "aiming always at two goals: the coherence of an oriented discourse and the irrealization of this discourse through formal beauty, never losing sight of one or the other under the pain of falling into incoherence or pure information" (II, 1620). Yet as Sartre analyzes the interaction of the signifying and the nonsignifying in Flaubert, the relationship tends to become one-directional and to be explained in terms of the theory of the imagination that Sartre enunciated as early as L'Imaginaire. ${ }^{4}$ The signifying in Flaubert is simply a means to the nonsignifying, and his realism is mere appearance that veils the activity of the pure imagination (III, 20). The goal of Flaubert's writing is pure art as the nihilating and nihilistic force that derealizes reality and language itself in favor of an impossible quest for imaginary totalization. This imaginary totalization is further identified by Sartre as Flaubert's lived experience which is neurotically passive and can be communicated only indirectly through "style." Paradoxically, Sartre is able to

3. Ibid., 432.

4. (Paris: Gallimard, 1940); Bernard Frechtman, trans., The Psychology of the Imagination (New York: Washington Square Press, 1966). 


\section{Madame Bovary on Trial}

name the unsayable and to fixate the uncanny effects of Flaubert's writing: l'indisable is Flaubert's neurotic experience as a passive object of language which the adult writer takes from the child and converts into a "passivized" project or option subie. Thus Sartre's analysis of Flaubert's "style" ultimately joins up with the interpretation we have discussed in the last chapter, and it thereby tends to circumvent the knotty problem of the relations among the symptomatic, the critical, and the more radically disorienting features of Flaubert's writing.

Sartre's own theory of the imagination, which he sees as covering Flaubert's writing practice, itself presents the relation between the imagination and reality in dichotomous and onedimensional terms: the imaginary nihilates the real in the impossible desire for "totalization" in the form of absence or unreality. I have already suggested that this "theory" applies at best to the most extreme and unqualified side of the quest for pure art. Indeed it is less a general theory of the imagination than a hyperbolically unilinear expression of imaginary desire which verges on hysterical withdrawal and paranoid schizophrenia. In any event, it neglects the productive and reproductive interaction between the imagination and reality as well as the possible problematization of the boundary between the imaginary and the real-what Flaubert found in Cervantes and what Freud discussed as the "uncanny." In Sartre's theory, one has an arrested dialectic of the real and the imaginary and little room for a readjustment of the boundaries between the two. There is only the passage from the one to the other in an impossible quest for total purity or transcendence that is tantamount to total absence. Given this "theory," it is not surprising that Sartre's account tends to stress the life of the author and to employ the writings as symptomatic evidence of authorial experience most often construed as "neurotic": "The Flaubertian revolution comes from the fact that this writer, mistrusting language from childhood, begins, in contrast to the classics, to pose the principle of the non-communicability of lived experience [le vécu]" (II, 1986). Whether Sartre's speculation applies to the author or not, it tends to lose sight of the writer and of the text in the use of language that can harbor the project of imaginary "derealization" only as one tendency- 
more precisely as an impossible quest for a transcendental absolute-in a complex and internally contestatory field of forces. The problem here is not whether one has an either/or choice between existential man masterfully speaking language and structural man passively being spoken by language. It is rather that of the actual and desirable relations between active and receptive roles in the relation of speaker or writer to language. As Sartre himself intimates, writing or speaking as uses of language are not constitutive of pure theory in contrast to pure practice-a vision that easily lends itself to a hypostatized and simplistic opposition between the study and the streets. The comprehensive question is that of the ways in which the use of language as a material and a signifying practice is articulated with reference to related activities. This question is the larger frame for discourse analysis.

Here a further feature of Sartre's approach may be noted. Even on the level of larger units of discourse analysis, Sartre's treatment of narration in Flaubert focuses almost exclusively on impersonal or impassive narration in which Sartre finds a "principe de survol" coinciding with the desire for imaginary transcendence. He does not treat the larger narrative context in which impersonal narration takes place. It is quite remarkable that Sartre says nothing about Flaubert's so-called "free indirect style" which for other commentators was Flaubert's most pronounced stylistic contribution to the history of the novel.

Flaubert's use of the "free indirect style" is a telling instance of the intricate fashion in which Sartre's conception of Flaubert as an antihuman ideologist and stylist of pure art is qualified, indeed contested, by a significant set of factors that Sartre does relatively little to elucidate. Perhaps the most insistent of these factors is the way art always harbors some "complicity" with traditional or situational "givens," may effect a critical disclosure or imaginative reworking of them, and possibly engages in dizzying movements of radical ambivalence that, while not simply denying the importance of tradition and its critique, do stimulate those dreamlike overtures that Flaubert saw as the exploding stars or black holes of the aesthetic process. 